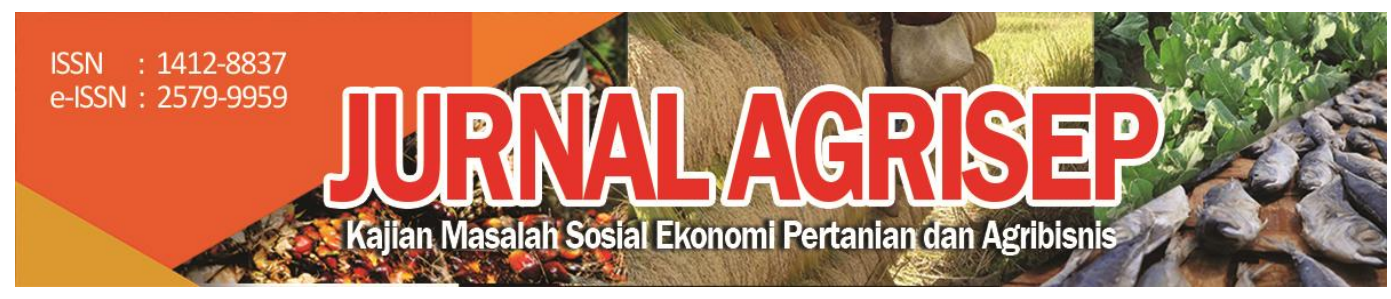

DOI: 10.31186/jagrisep.18.2.359-370

\title{
PREFERENSI PETANI DALAM MENGHADAPI RISIKO PRODUKSI CABAI MERAH KERITING DI KABUPATEN CIANJUR
}

\author{
Farmers' Preference in Facing the Production Risk of Red Chili in \\ Cianjur District
}

\author{
Irawan Wibisonya $ه ;$; Anna Fariyanti; Siti Jahroh \\ Departemen Magister Sains Agribisnis Fakultas Ekonomi dan Manajemen \\ Institut Pertanian Bogor \\ Email: irawanwibisonya@yahoo.co.id
}

\begin{abstract}
One indication of the risk is fluctuations in production yield. Chili as a superior competitor is the most vulnerable to fluctuations in production. The purpose of this study was to analyze the factors that influence the risk of production and farmers' policies on the risk of production. This research used purposive sampling with 66 farmers sampel size. This research used Just and Pop models which were analyzed using regression analysis and analysis of farmer relationships with utility function models. The results reflected that land area, seeds, fertilizers, pesticides and labor can increase the yield of chili. While the area of land, seeds, fertilizers, labor and planting seasons can increase the risk of chili production. Most farmers have risk takers compared to the potential for chili production.
\end{abstract}

Keywords: preference, production, risk production, red chili

\section{ABSTRAK}

Salah satu indikasi adanya risiko yaitu fluktuasi terhadap hasi produksi. Cabai sebagai komoditas unggulan merupakan yang paling rentan mengalami fluktuasi dalam produksi. Tujuan daripenelitian ini adalah untuk menganalisis faktor-faktor yang mempengaruhi risiko produksi dan perilaku petani terhadap risiko produksi. Penelitian ini menggunakan purposive sampling dengan 66 petani. Penelitian ini menggunakan model Just dan Pop yang dianalisi menggunakan analisis regresi serta analisis perilaku petani dengan model fungsi utilitas. Hasil menunjukkan bahwa luas lahan, benih, pupuk, pestisida dan tenaga kerja dapat meningkatkan hasil produksi cabai. Sedangkan luas 
lahan, benih, pupuk, tenaga kerja dan musim tanam dapat meningkatkan risiko produksi cabai. Sebagian besar petani memiliki sifat risk taker terhadap adanya risiko produksi cabai.

Kata kunci: preferensi, produksi, risiko produksi, cabai merah

\section{PENDAHULUAN}

Cabai (Capsicum annuum $L$ ) termasuk salah satu komoditi sayuran yang mempunyai nilai ekonomi yang cukup tinggi, karena peranannya yang cukup besar untuk memenuhi kebutuhan domestik sebagai komoditi ekspor dan industri pangan (Hartuti dan Sinaga 1997). Kebutuhan cabai untuk kota besar yang berpenduduk satu juta atau lebih sekitar 66000 ton/bulan. Pada musim hari besar keagamaan, kebutuhan cabai biasanya meningkat sekitar 10 sampai 20 persen dari kebutuhan normal. Tingkat produktivitas cabai secara nasional selama 5 tahun terakhir sekitar 6 ton/ha. Untuk memenuhi kebutuhan bulanan masyarakat perkotaan diperlukan luas panen cabai sekitar $11000 \mathrm{ha} / \mathrm{bulan}$, sedangkan pada musim hari besar keagamaan luas area panen cabai yang harus tersedia berkisar antara 12100 - 13300 ha/bulan. Selain itu, kebutuhan cabai untuk masyarakat pedesaan atau kota-kota kecil serta untuk bahan baku olahan. Selama 2016 volume ekspor cabai ke beberapa negara mencapai 433828 ton dan nilai ekspor US\$ 587079 (Kementerian Pertanian 2016).

Kontribusi produksi cabai Indonesia lebih didominasi oleh produksi dari pulau Jawa. Berdasarkan rata-rata produksi tahun 2011 sampai 2015, Jawa Barat memberikan kontribusi sebesar 22.95 persen terhadap total produksi cabai Indonesia, Sumatera Utara 17.94 persen, Jawa Tengah 14.68 persen, Jawa Timur 9.59 persen, Sumatera Barat 5.83 persen, Aceh 4.56 persen dan Bengkulu sebesar 3.77 persen (Kementerian Pertanian 2016).

Pada tahun 2014 komoditas cabai telah menjadi komoditas pokok nasional dan perlu dikembangkan. Selama 2014 cabai berkontribusi sebesar 6.72 persen atas produksi sayuran Indonesia dengan total produksi 1074602 ton. Sehingga hal ini perlu dilakukan pengembangan terhadap komoditas cabai agar terus meningkat. Pengembangan yang dilakukan berdasarkan cluster yang difokuskan untuk mendorong pertumbuhan ekonomi kawasan. Salah satu sasaran pengembangan yang perlu dilakukan diutamakan untuk peningkatan ekspor (Kementerian Pertanian 2015).

Salah satu jenis cabai yang banyak dikonsumsi di Indonesia adalah jenis cabai merah. Selama 2011 sampai 2015 (Kementerian Pertanian 2016) total konsumsi cabai merah di Indonesia mencapai $7.57 \mathrm{Kg} /$ Kapita lebih besar bila dibandingkan cabai rawit sebesar $6.46 \mathrm{Kg} /$ Kapita dan cabai hijau yang sebesar $1.07 \mathrm{Kg} /$ Kapita. Cabai merah banyak dikonsumsi masyarakat baik untuk dikonsumsi rumah tangga maupun industri makanan. Hal ini menjadi penting selain potensi cabai merah yang memiliki prospek yang cerah namun disisi lain 
perlu untuk bagaimana dapat menstabilkan pasokan cabai merah agar dapat tetap mudah dikonsumsi masyarakat.

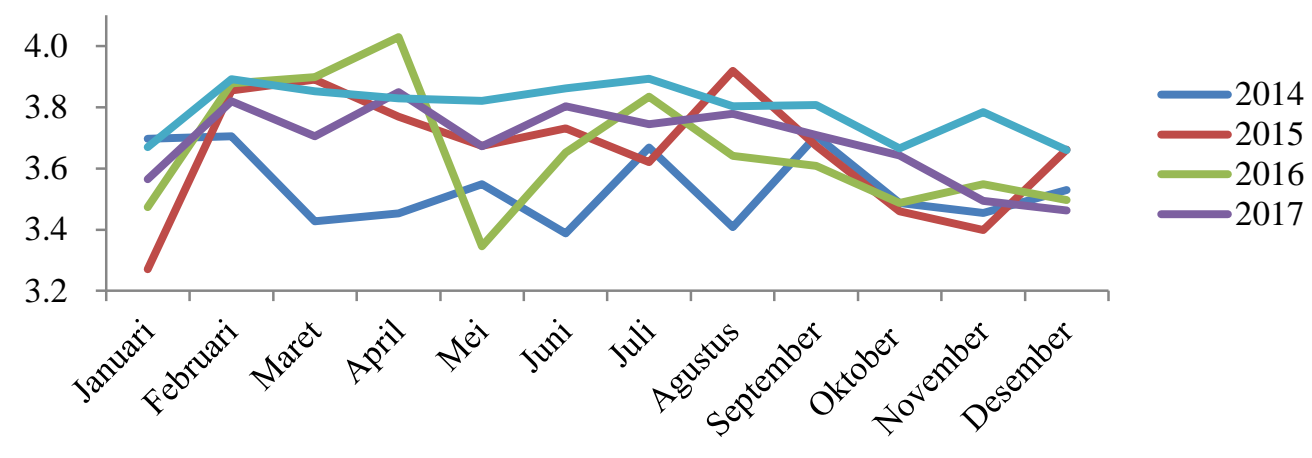

Gambar 1

Perkembangan Produktivitas Bulanan Cabai Merah di Indonesia 2014-2017

Sumber: Direktorat Jenderal Hortikultura (2019)

Perkembangan produktivitas cabai merah di Indonesia dalam waktu 5 tahun terakhir dalam tiap bulannya cenderung mengalami fluktuasi. Hal ini terlihat dari pergerakan produktivitas cabai merah pada Gambar 1. Fluktuasi produktivitas cabai merah ini dapat mengindikasikan adanya gap produksi cabai merah yang merupakan ciri dari risiko produksi cabai merah di Indonesia. Risiko produksi pada cabai merah dapat berasal dari berbagai sumber seperti iklim, sumber daya manusia, hama dan penyakit, serta lainnya, yang secara menyeluruh dapat memberikan dampak kerugian bagi petani. Dampak dari risiko produksi dapat berupa penurunan kualitas cabai merah ataupun penurunan jumlah produksi.

Salah satu risiko dalam produksi yang bersumber dari eksternal dan sulit diperkirakan adalah iklim. Terjadinya perubahan iklim yang ekstrim berdampak cukup besar terhadap tanaman semusim. Salah satu unsur cuaca yang dapat digunakan sebagai indikator dalam kaitannya dengan tanaman adalah curah hujan. Mengingat curah hujan merupakan unsur iklim yang fluktuasinya tinggi dan pengaruhnya terhadap produksi tanaman cukup signifikan. Jumlah curah hujan secara keseluruhan sangat penting dalam menentukan hasil produksi pertanian (Anwar et al. 2015).

\section{METODE PENELITIAN}

Penelitian ini dilakukan di Kecamatan Sukanagara dan Kecamatan Pacet, Kabupaten Cianjur, Jawa Barat. Pemilihan lokasi didasarkan karena Kecamatan Sukanagara merupakan sentra produksi cabai merah di Kabupaten Cianjur dengan produksi sebesar 33093 ton pada 2016. Sedangkan Kecamatan Pacet 
dipilih karena merupakan daerah pengembangan kawasan cabai. Penelitian ini dilakukan pada waktu November 2017 hingga Januari 2018.

Pengambilan sampel dalam penelitian ini dilakukan secara purposive. Petani yang dipilih adalah petani yang telah atau sedang mengusahakan cabai merah keriting pada saat penelitian, karena data terbaru mengenai jumlah populasi petani cabai merah keriting di Kabupaten Cianjur tidak tersedia. Seluruh petani yang menjadi sampel adalah petani cabai merah keriting di Kecamatan Sukanagara dan Kecamatan Pacet, Kabupaten Cianjur, Jawa Barat. Jumlah sampel yang diambil yaitu sebanyak 66 petani. Sebanyak 36 orang petani dipilih di Kecamatan Sukanagara, sedangkan sebanyak 30 orang dipilih di Kecamatan Pacet.

Data yang telah dikumpulkan selanjutnya dianalisis secara kuantitatif dan kualitatif dengan pendekatan deskriptif. Analisis deskriptif dilakukan untuk mengetahui karakteristik responden. Untuk menganalisis permasalahan pertama menggunakan model fungsi produksi Just dan Pope dengan menggunakan analisis regresi linear berganda, dan permasalahan kedua menggunakan analisis perilaku petani dengan model fungsi utilitas.

\section{Analisis Risiko Produksi}

Asche dan Tveteras (1999) menjelaskan bahwa fungsi produksi dalam model Just dan Pope yang menggunakan prosedur dua langkah. Dalam menganalisis fungsi produksi dan fungsi risiko cabai merah keriting diasumsikan menggunakan model fungsi tipe Cobb-Douglas. Selanjutnya model Cobb-Douglas akan diregresikan dengan metode Ordinary Least Square (OLS). Berdasarkan hasil penelitian terdahulu dan menyesuaikan dengan kondisi dilapangan, maka faktor produksi yang mempengaruhi produksi cabai merah keriting, yaitu luas lahan, benih, pestisida, pupuk, tenaga kerja, dan dummy musim. Fungsi produksi dan risiko produksi cabai merah sebagai berikut:

$$
y=f(x, \alpha)+u=f(x, \alpha)+g(x, \beta) \varepsilon
$$

$$
\begin{aligned}
& \text { Fungsi Produksi } \begin{array}{l}
\mathrm{Y}=\mathrm{f}(\mathrm{X}) \\
\mathrm{f}(\mathrm{x})=\operatorname{Ln} \mathrm{Y}= \\
\quad \alpha 0+\alpha 1 \operatorname{LnX} 1+\alpha 2 \operatorname{LnX} 2+\alpha 3 \operatorname{LnX} 3+\alpha 4 \operatorname{LnX} 4+\alpha 5 \operatorname{LnX} 5 \\
+\alpha 6 \mathrm{D}+\epsilon
\end{array}
\end{aligned}
$$

Fungsi Risiko Produksi $\quad \varepsilon \mathrm{i} 2=(\mathrm{Yi}-\mathrm{Y} \hat{\mathrm{l}}) 2$

$$
\begin{aligned}
\mathrm{g}(\mathrm{x})=\operatorname{Ln} \varepsilon \mathrm{i} 2 & =\beta 0+\beta 1 \operatorname{LnX} 1+\beta 2 \operatorname{LnX} 2+\beta 3 \operatorname{LnX} 3+\beta 4 \operatorname{LnX} 4+\beta 5 \operatorname{LnX} 5 \\
& +\beta 6 \mathrm{D}+\epsilon
\end{aligned}
$$

Dimana $\mathrm{f}(\mathrm{x})$ adalah fungsi produksi; $\mathrm{g}(\mathrm{x})$ adalah fungsi risiko produksi; $\mathrm{Y}$ adalah produksi aktual (ton); $Y \hat{\imath}$ adalah produksi dugaan; $\mathrm{X}_{1}$ a adalah luasan lahan $(\mathrm{Ha}) ; X_{2}$ adalah benih $(\mathrm{Kg}) ; X_{3}$ adalah pestisida (Liter); $X_{4}$ adalah pupuk 
$(\mathrm{Kg}) ; \mathrm{X}_{5}$ adalah tenaga Kerja $(\mathrm{HOK}) ; \mathrm{D}$ adalah dummy iklim $(1=$ saat musim hujan, $0=$ saat musim kemarau); $\alpha_{1}, \alpha_{2}, \ldots \alpha_{6}$ adalah koefisien parameter dugaan produksi $X_{1}, X_{2}, X_{3}, \ldots X_{5} ; \beta_{1}, \beta_{2,}, \ldots . \beta_{6}$ adalah koefisien parameter dugaan risiko produksi $\mathrm{X}_{1}, \mathrm{X}_{2}, \mathrm{X}_{3}, \ldots \mathrm{X}$; dan $\epsilon$ adalah unsur error.

\section{Analisis Prefernsi Petani}

Pada penelitian ini diasumsikan bahwa petani dalam melakukan usahataninya berusaha untuk memaksimalkan utilitas dan maksimisasi utilitas didekati dengan maksimisasi pendapatan dalam berusahatani, dan petani mendapatkan hasil produksi y pada tingkat harga p, maka maksimisasi utilitas petani adalah utilitas (U) dari keuntungan (п) (Robison dan Barry 1987), maka :

$$
\begin{gathered}
\operatorname{Max} \mathrm{U}(\text { п) } \\
\pi=p \cdot y-r \cdot x-C
\end{gathered}
$$

dimana $\Pi$ adalah keuntungan usahatani; $r$ adalah harga input; $x$ adalah jumlah input yang digunakan; $C$ adalah biaya tetap usahatani; $p$ adalah harga output; y adalah output

Output usahatani adalah :

$$
Y=f(x)+g(x)
$$

Dengan mensubtitusikan persamaan Max U(п) ke dalam persamaan $Y$, maka diperoleh :

$$
U(\pi)=p \cdot f(x)+p \cdot g(x)-r \cdot x-C
$$

Fungsi utilitas untuk petani cabai merah [U(по)] adalah :

$$
U(\pi o)=p \cdot f(\mathrm{X} 1, \mathrm{X} 2, \ldots, \mathrm{X} 5)+p \cdot g(\mathrm{X} 1, \mathrm{X} 2, . . \mathrm{X} 5)-r i(\mathrm{X} 1, \mathrm{X} 2, . . \mathrm{X} 5,)-C
$$

Dimana $U($ по) adalah utilitas petani cabai merah; $f(x)$ adalah fungsi produksi; $\mathrm{g}(\mathrm{x})$ adalah fungsi risiko; $\mathrm{p}$ adalah harga output (Rp); ri adalah harga input ke-i (Rp); xi adalah jumlah input ke-i; $C$ adalah biaya tetap usaha tani; $X_{1}$ adalah Luasan lahan $\left(\mathrm{m}^{2}\right) ; X_{2}$ adalah Benih $(\mathrm{kg} / \mathrm{musim}) ; X_{3}$ adalah Pestisida (liter/musim); $X_{4}$ adalah Pupuk $\left(\mathrm{Kg} /\right.$ musim); $X_{5}$ adalah Tenaga Kerja (HOK).

Dari persamaan di atas, dicari First Order Condition (FOC) dan Second Order Condition (SOC) yang selanjutnya digunakan untuk menganalisis nilai perilaku risiko petani dengan mengadopsi Arrow-Pratt absolute risk aversion (AR) yang diperoleh dari rasio antara nilai SOC dan FOC dari fungsi utilitas, sebagai berikut: 


$$
\mathrm{AR}=-\frac{U^{\prime \prime}(\pi)}{U^{\prime}(\pi)}
$$

Dimana AR adalah Absolute risk averse; U'(ni) adalah First Order Condition dari fungsi utulitas; dan U'"(ni) adalah Second Order Condition dari fungsi utilitas

\section{HASIL DAN PEMBAHASAN}

\section{Analisis faktor-faktor yang Mempengaruhi Produksi Cabai Merah Keriting}

Model pendugaan untuk fungsi produksi cabai merah keriting didapat dengan memasukkan faktor input produksi sebagai variabel independen dan produksi cabai merah keriting sebagai variabel dependen. Pengaruh faktor produksi terhadap risiko produksi ini didapat dengan melihat pengaruh faktor produksi. Faktor-faktor yeng menjadi variabel bebas dalam model merupakan faktor-faktor produksi yang diduga dapat mempengaruhi produksi cabai merah keriting yang dihasilkan.

Tabel 1 Hasil pendugaan fungsi produksi dan fungsi risiko usahatani cabai merah keriting di Kabupaten Cianjur

\begin{tabular}{lcccc}
\hline \multirow{2}{*}{ Variabel } & \multicolumn{2}{c}{ Fungsi Produksi } & \multicolumn{2}{c}{ Fungsi Risiko } \\
\cline { 2 - 5 } & $\begin{array}{c}\text { Koefisien } \\
\text { Regresi }\end{array}$ & p-value & $\begin{array}{c}\text { Koefisien } \\
\text { Regresi }\end{array}$ & P-Value \\
\hline Constant & 5.791 & 0.000 & 21.444 & 0.000 \\
Ln Benih & 0.152 & $0.165^{*}$ & 0.329 & 0.588 \\
Ln Pupuk & 0.077 & $0.146^{*}$ & -0.605 & $0.043^{* *}$ \\
Ln Pestisida & 0.210 & $0.000^{* *}$ & 0.097 & 0.754 \\
Ln Tenaga Kerja & 0.224 & $0.017^{*}$ & -0.445 & 0.385 \\
Dummy Musim & -0.339 & 0.972 & 2.896 & $0.000^{* * *}$ \\
& \multicolumn{2}{c}{ Adj $\mathrm{R}^{2}=0.477$} & \multicolumn{2}{c}{ Adj $\mathrm{R}^{2}=0.275$} \\
\hline
\end{tabular}

Keterangan: ${ }^{* * *}=0.05(5 \%)^{* *}=0.10(10 \%)^{*}=0.20(20 \%)$

Pendugaan terhadap fungsi produksi cabai merah keriting menunjukkan bahwa pendugaan parameter terhadap variabel benih memiliki pengaruh secara signifikan terhadap tingkat produksi cabai. Semakin banyaknya penggunaan benih maka semakin meningkat produksi cabai merah keriting yang dihasilkan. Sebagian besar petani menggunakan benih dengan jenis varietas bianka dan OR 42. Dalam penggunaan benih para petani tergolong selektif dan fanatik terhadap satu varietas saja. Rata-rata penggunaan benih petani sampel sebanyak 0.17 $\mathrm{kg} / \mathrm{ha}$. Penggunaan benih yang berpengruh terhadap produksi cabai merah keriting ini sejalan dengan penelitian Saptana (2011) dimana pada hasil

364 Irawan Wibisonya; Anna Fariyanti, Siti Jahroh; Preferensi Petani... 
penelitiannya menyebutkan bahwa variabel benih tanaman berpengaruh positif terhadap produksi cabai merah besar dan cabai merah keriting di Jawa Tengah. Secara risiko, benih juga mendapatkan nilai positif namun tidak singnifikan. Hal ini megindikasikan bahwa penambahan penggunaan benih dapat menimbulkan risiko produksi dikemudian hari. Nurhapsa (2013) dan Qomaria (2011) dimana bibit merupakan input yang meningkatkan risiko pada produksi kentang dan talas. Namun berbeda dengan (Tiedeman dan Lohmann 2012) menyatakan bahwa bibit merupakan input yang dapat mengurangi risiko produksi.

Dalam penggunaannya, pupuk memiliki pengaruh yang signifikan terhadap tingkat produksi cabai. Pada setiap penambahan input pupuk maka akan menambahkan pula tingkat produksi cabai yang didapat. Secara teknis, pupuk mampu berperan menjaga kesuburan tanah yang ditanami cabai. Sehingga tanaman dapat tumbuh secara optimal. Variabel pupuk dalam penelitian ini terdiri dari pupuk kimia dimana di dalamnya meliputi pupuk urea, ououk NPK Phonska, pupuk KCL, pupuk ZA, Pupuk TSP dan pupuk SP36 dan juga pupuk organik. Menurut Saptana (2011) dalam penelitiannya menyebutkan bahwa variabel pupuk yang di dalamnya terdapat pupuk kimia dan pupuk organik berpengaruh positif terhadap peningkatan produksi cabai merah besar dan cabai merah keriting di Jawa Tengah. Secara risiko, pemberian input produksi dapat mengurangi risiko produksi cabai merah keriting. Hasil estimasi variabel pupuk mengurangi risiko ini sejalan dengan penelitian Guan dan Wu (2009), Suharyanto (2013) dan Asnah et al. (2015).

Sama halnya dengan pupuk, pestisida merupakan instrumen penting dalam upaya peningkatan produksi cabai merah keriting. Terbukti dengan hasil perhitungan variabel pestisida yang bernilai positif dan signifikan dalam taraf nyata 5 persen. Hasil ini membuat pestisida merupakan variabel input yang dapat mendorong kenaikan produksi cabai merah keriting. Jenis pestisida yang digunakan untuk sebagian besar petani yaitu jenis insektisida dan juga fungisida. Hal ini dikarenakan lebih banyak hama dan penyakit yang menyerang tanaman cabai merah keriting di lokasi penelitian. Dalam fungsi risiko, pemberian pestisida dapat meningkatkan risiko produksi cabai merah keriting.pemberian pestisida yang berlebihan juga dapat meningkatkan risiko produksi cabai merah. Hasil estimasi penggunaan pestisida ini sejalan dengan penelitian yang dilakukan oleh Epinoza dan Rand (2015) serta Nurhapsa (2013) dimana penunaan pestisida yang tidak tepat mampu dapat meningkatkan risiko.

Tenaga kerja juga berperan dalam keberhasilan suatu capaian produksi, pada penelitian ini tenaga kerja berpengaruh dalam meningkatkan hasil produksi cabai merah keriting. Variabel tenaga kerja memiliki pengaruh nyata dengan taraf kepercayaan 5 persen. Hasil ini sejalan dengan penelitian yang dilakukan oleh Rahayu (2011) bahwa tenaga kerja memberikan pengaruh positif terhadap peningkatan hasil produksi usahatani. Tenaga kerja di dalam fungsi risiko produksi juga dapat berperan sebagai pengurang timbulnya risiko, tenaga 
kerja yang terampil dan menguasai seluk beluk budidaya cabai dapat meminimalisir timbulnya risiko yang berasal dari kesalahan dalam budidaya. Hasil ini sejalan dengan yang ditemukan oleh Fauziyah (2010), Rahayu (2011), Nurhapsa (2013) dan Apriana (2017), dimana dalam fungsi risiko input tenaga kerja merupakan komponen yang mampu mengurangi risiko produksi.

Sebagian besar petani responden lebih sering melakukan tanam cabai di musim kemarau. Selain tidak terkendala dengan pasokan air, musim hujan yang terjadi terkadang cenderung ekstrem dan dapat merusak tanaman. Namun pada penelitian ini, produksi cabai di lokasi penelitian yang ditanam pada musim hujan lebih tinggi daripada produksi tanaman cabai merah keriting yang ditanam pada saat musim kemarau. Selain itu, hasil tersebut mengartikan bahwa varian produksi cabai merah keriting di Kabupaten Cianjur pada musim tanam hujan lebih beresiko dari pada produksi di waktu musim kemarau.

\section{Preferensi Petani dalam Menghadapi Risiko Produksi Cabai Merah Keriting}

Setelah mengetahui risiko produksi yang dihadapi petani dalam usahatani cabai merah keriting, maka perlu juga mengetahui bagaimana sikap petani dalam menghadapi risiko. Dalam melakukan estimasi terhadap nilai preferensi risiko atau nilai Absolute Risk averse (AR), petani dapat dikatakan risk averse jika memiliki nilai AR lebih besar dari 0, petani dikatakan risk neutral jika memiliki nilai AR sama dengan 0 , serta petani dikatakan risk taker jika memiliki nilai AR kurang dari 0.

Tabel 2 Preferensi risiko produksi petani cabai merah keriting di Kabupaten Cianjur terhadap penggunaan input produksi

\begin{tabular}{lcc}
\hline \multicolumn{1}{c}{ Input Produksi } & Rata-rata nilai AR & Preferensi Risiko \\
\hline Benih & 0.0125752373 & Risk Averse \\
Pupuk & -0.0000244403 & Risk Taker \\
Pestisida & -0.0000000011 & Risk Taker \\
Tenaga Kerja & -0.0000334246 & Risk Taker \\
\hline
\end{tabular}

Berdasarkan hasil penelitian, didapati bahwa penggunaan input pupuk, pestisida dan tenaga kerja bersifat risk taker. Petani cabai merah keriting di Kabupaten Cianjur berani menggunakan input pupuk, pestisida, dan tenaga kerja untuk meningkatkan produksi meskipun menghadapi risiko. Sedangkan untuk pengunaan input benih, petani sampel bersifat risk averse.

Petani cabai merah keriting di lokasi penelitian sebagian besar berperilaku risk averse dalam penggunaan input benih. Petani yang memiliki sifat risk averse ini akan sedikit mengurangi dan tidak berani meningkatkan penggunaan input benihnya dalam kegiatan usahatani cabai merah keriting saat kondisi risiko. 
Selain itu di lapangan sebagian besar petani yang fanatik terhadap varietas tertentu juga membuat petani tidak berani menggunakan varietas lainnya. Beberapa petani bahkan menunda tanam ketika tidak mendapatkan benih yang sesuai, sebagian petani tetap menanam dengan varietas lain namun dengan skala usaha yang lebih kecil. Penggunaan benih ini terkait dengan kualitas benih yang mampu menghasilkan cabai lebih banyak sekaligus menghasilkan tanaman cabai yang tidak mudah terdampak akan serangan hama dan penyakit. Hasil ini sejalan dengan penelitian yang dilakukan oleh Rahayu (2011) yang menemukan bahwa sebagian besar petani padi organik di Kabupaten Sragen bersifat risk averse dalam penggunaan benih padi.

Perilaku petani dalam menggunakan pupuk menunjukkan bahwa petani sampel merupakan petani yang berani mengambil risiko. Penggunaan pupuk kimia di lokasi penelitian rata-rata sebanyak $224 \mathrm{~kg}$ dan masih dapat dilakukan penambahan pupuk kimia hingga mendapati standar penggunaan pupuk kimia yang ditentukan dinas pertanian yang berkisar antara 270 higga $330 \mathrm{~kg} / \mathrm{ha}$. Begitu juga dengan penunaan pupuk kandang yang saat ini rata-rata penggunaannya masih sebesar 2.8 ton. Namun begitu untuk pupuk kimia komposisi yang digunakan antar petani relatif sama. Hasil ini sejalan dengan penelitian yang dilakukan oleh Hidayati (2016) dan Apriana (2017) dimana preferensi risiko petani terhadap penggunaan input pupuk adalah risk taker.

Penggunaan pestisida oleh petani sampel cenderung bersifat prefentif, petani bersedia mengeluarkan biaya lebih untuk penggunaan pestisida walaupun risiko produksi yang diterima belum pasti. Petani dalam penggunaannya tidak terlepas dari pengalaman selama berusahatani cabai merah keriting sebelumnya. Karena berbeda dengan pupuk untuk penggunaan pestisida tidak memiliki standar ketentuan penggunaan, sehingga antar petani memiliki jumlah penggunaan pestisida yang berbeda. Banyak petani yang bersifat preventif dalam penggunaan pestisida dikarenakan keberlangsungan tanaman cabai merah keriting bergantung pada penanganan terhadap hama dan penyakit. Petani yang bersifat risk taker dalam penggunaan pupuk ini sejalan dengan penelitian Nurhapsa (2013) dan Apriana (2017) yang menunnjukan bahwa petani cenderung memiliki sifat risk taker dalam penggunaan pestisida untuk tanaman kentang dan padi. Namun berbeda dengan Hidayati (2016) yang menemukan bahwa terdapat petani yang memiliki sifat risk averse terhadap penggunaan pupuk.

Tenaga kerja merupakan input yang banyak mengeluarkan biaya selama produksi usahatani. Namun petani cabai merah keriting dalam menggunakan tenaga kerja tetap sesuai dengan kebutuhan, keseluruhan petani juga menggunakan tenaga kerja dari luar keluarga. Besaran biaya tenaga kerja di lokasi penelitian yaitu antara Rp 40000 hingga Rp 50000 dengan durasi waktu kerja antara 5 - 7 jam per hari. Tetapi hal ini tidak menutup untuk petani menambah tenaga kerjanya dikemudian hari. Walaupun untuk saat ini 
ketersediaan tenaga kerja di lokasi penelitian terbatas. Hasil estimasi ini sesuai dengan Fauziyah (2010) dan Apriana (2017) yang masing-masing medapatkan bahwa preferensi petani terhadap penggunaan tenaga kerja adalah risk taker. Namun berbeda dengan Fariyanti (2008) dan Nurhapsa (2013) dimana preferensi risiko produksi petani terhadap tenaga kerja bersifat risk averse.

Hasil estimasi secara menyeluruh menunjukkan bahwa peferensi risiko petani untuk keseluruhan input menunjukkan bahwa seluruh petani cabai merah keriting yang ada di lokasi penelitian bersifat risk taker. Rata-rata nilai AR seluruh petani sampel yakni sebesar -0.025. walaupun tanaman cabai merah keriting merupakan salah satu tanaman yang paling rentan terhadap serangan hama dan penyakit, petani tetap melakukan usahatani cabai merah keriting secara rutin, terlebih di Kecamatan Sukanagara yang sebagian besar wilayahnya merupakan petani cabai merah keriting.

Hasil penelitian yang didapat ini sejalan dengan Apriana (2017) dan Rahayu (2011) dimana pada penelitiannya petani padi bersifaat risk taker terhadap adanya risiko. Namun berbeda dengan Fariyanti (2008) menemukan bahwa dengan adanya risiko produksi menyebabkan rumahtangga petani sayuran berperilaku risk averse. Begitu juga Fauziyah (2010) juga menemukan bahwa petani tembakau di Kabupaten Pamekasan sebagian besar memiliki perilaku sebagai risk averse. Selain itu, Villano (2005), Kumbhakar (2001) dan Kahan (2008) yang menemukan hal yang sama yaitu petani yang bersifat risk averse, sehingga petani lebih memilih berpendapatan rendah dari pada merugi.

\section{SIMPULAN DAN SARAN}

\section{Simpulan}

Faktor-faktor produksi seperti penggunaan benih, pupuk, pestisida dan tenaga kerja merupakan faktor yang dapat menambah tingkat produksi cabai merah keriting, sedangkan musim tanam merupakan faktor yang dapat mengurangi produksi cabai merah keriting. Untuk tingkat risiko produksi, faktor-faktor seperti benih, pestisida dan musim tanam merupakan faktor-faktor yang dapat meningkatkan risiko produksi cabai merah keriting. Sedangkan penggunaan pupuk dan tenaga kerja mampu menjadikan faktor input mengurangi tingkat risiko produksi cabai merah keriting.

Preferensi risiko petani terhadap penggunaan input usahatani berupa pupuk, pestisida dan tenaga kerja adalah bersifat risk taker, sedangkan dalam penggunaan benih petani cenderung bersifat risk averse. Secara keseluruhan petani di Kabupaten Cianjur memiliki sifat risk taker terhadap adanya risiko produksi cabai merah keriting. 


\section{Saran}

Kurangnya informasi kepada petani terkait pengunaan input pupuk menjadi salah satu kendala yang harus dapat segera ditangani. Diharapkan ada peran lebih penyuluh dalam mensosialisasikan kembali pengunaan pupuk yang tepat.

\section{DAFTAR PUSTAKA}

Anwar MR, Liu DL, Farquharson R, Macadam I, Abadi A, Finlayson J, Wang B, Ramilan T. 2015. Climate change impacts on phenology and yields of five broadacre crops at four climatologically distinct locations in Australia. Agricultural Systems 132: 133-144.

Apriana N. 2017. Analisis Risiko Produksi Petani Padi di Daerah Aliran Sungai Bengawan Solo, Kabupaten Bojonegoro, Provinsi Jawa Timur. [Tesis]. Bogor (ID): Institut Pertanian Bogor.

Asche F, Tveteras R. 1999. Modeling production risk with a two-step prosedure. Journal of Agricultural and Resource Economics 24(2):424-439.

Asnah, Masyuri, Jangkung HM, Slamet H. Tinjauan Teoritis dan Empiris Efisiensi, Risiko dan Perilaku Risiko Usaha Tani serta Implikasinya dalam Upaya Pencapaian Swasembada Pangan. Forum Penelitian Agro Ekonomi. 33(2);81-94

Direktorat Jenderal Hortikultura. 2019. Data Luas Panen dan Produksi Cabai Merah di Indonesia Tahun 2014-2018. Jakarta (ID): Sesditjen Horti

Epinoza CS, Rand JH. 2015. Pesticide Use and Agricultural Risk. The Case of Rice Producers in Vietnam. The Latin American and Caribbean Economic Association.

Fariyanti A. 2008. Perilaku Ekonomi Rumahtangga Petani Sayuran dalam Menghadapi Risiko Produksi dan Harga Produk di Kecamatan Pangalengan Kabupaten Bandung [Disertasi]. Bogor (ID): Institut Pertanian Bogor.

Fauziyah E. 2010. Pengaruh Perilaku Petani dalam Menghadapi Risiko Produksi terhadap Alokasi Input Usahatani Tembakau: Pendekatan Fungsi Produksi Frontir Stokastik [Disertasi]. Bogor (ID): Institut Pertanian Bogor.

Guan Z, Wu F. 2009. Specification and Estimation of Heterogeneous Risk Preference. Beijing, China. Contributed Paper prepared for Presentation at the 27th International Conference of Agricultural Economists (IAAE). 
Hartuti N, Sinaga R M. 1997. Pengeringan Cabai. Balai Penelitian Tanaman Sayuran. (ID): Bandung

Hidayati R. 2016. Pengaruh Efisiensi Teknis dan Preferensi Risiko Petani Terhadap Penerapan Usahatani Kubis Organik di Kecamatan Baso Kabupaten Agam Sumatera Barat [Tesis]. Bogor (ID): Institut Pertanian Bogor.

Kahan D. 2008. Managing risk in farming. Food and Agriculture Organization of United Nations

Kementerian Pertanian Direktorat Jenderal Hortikultura. 2015. Statistik Produksi Hortikultura 2014. (ID) : Jakarta

Kementerian Pertanian Direktorat Jenderal Hortikultura. 2016. Program Peningkatan Produksi Dan Produktivitas Hortikultura Ramah Lingkungan Tahun 2015. (ID) : Jakarta

Kumbhakar S. 2001. Specification and Estimation of Production Risk, Risk Preferences and Technical Efficiency. American Journal of Agricultural Economics. 84(1):8-22.

Nurhapsa. 2013. Analisis Efisiensi Teknis dan Perilaku Risiko Petani serta Pengaruhnya terhadap Penerapan Varietas Unggul pada Usahatani Kentang di Kabupaten Enrekang Provinsi Sulawesi Selatan [Disertasi]. Bogor (ID): Institut Pertanian Bogor.

Qomaria N. 2011. Analisis Preferensi Risiko dan Efisiensi Teknis Usahatani Talas di Kota Bogor [Tesis]. Bogor (ID): Institut Pertanian Bogor.

Rahayu RB. 2011. Preferensi Risiko Petani pada Usahatani Padi Organik di Kabupaten Sragen [Tesis]. Bogor (ID): Institut Pertanian Bogor.

Robinson LJ, PJ Barry. 1987. The Competitive Firm's Response to Risk. Macmillan Publisher, London.

Saptana. 2011. Efisiensi Produksi dan Perilaku Petani Terhadap Risiko Produktivitas Cabai Merah di Provinsi Jawa Tegah [Disertasi]. Bogor (ID): Institut Pertanian Bogor.

Suharyanto. 2015. Analisis Risiko Produksi Padi Saah di Provinsi Bali. Journal of Agribusiness and Rural Development Research. 1(2):70-77

Tiedemann T, Lohmann UL. 2012. Production Risk and Technical Efficiency in Organic and Conventional Agriculture: The Case of Arable Farm in Germany. Journal of Agricultural Economics. 64(1):73-96

Villano R, E Fleming. 2005. Technical Inefficiency and Production Risk in Rice Farming : Evidence from Central Luzon Philippines. Asian Economic Journal. 20(1) : 29-49. 